\title{
THE SNOWBALL EFFECTS OF PRACTICES THAT COMPROMISE THE CREDIBILITY AND INTEGRITY OF HIGHER EDUCATION
}

\author{
C. S. Moyo* \\ e-mail: Moyo.C@che.ac.za
}

\author{
A. Saidi* \\ e-mail: Saidi.A@che.ac.za \\ ${ }^{*}$ Quality Assurance and Promotion Coordination Directorate \\ Council on Higher Education (CHE) \\ Pretoria, South Africa
}

\section{ABSTRACT}

Practices that compromise the credibility and integrity of higher education have been reported globally. These take place at all stages in the higher education delivery value chain, from student admission to assessment (including tests, assignments and examinations) and certification. Even in research-based postgraduate studies, the bane of plagiarism continues to evolve with time as dishonest students and academics relentlessly find ways of cheating the system. The central thesis of this article is that the negative consequences of the acts or practices that compromise the credibility and integrity of higher education do not only affect individuals, but they also affect the entire cohort of students, the higher education institution concerned, the broad higher education sector, the economic system and the socio-cultural system. Therefore, these practices have a snowball effect on the entire education system. The article argues that, overall, these practices result in "inequity among and unfairness" to individuals. It is, therefore, of paramount importance that sustainable solutions of curbing this social ill are explored and implemented because dealing with consequences will be too costly.

Keywords: credibility, effect(s), higher education, integrity, internationalisation, qualifications.

\section{INTRODUCTION}

Academic integrity is about observing the fundamental values which ought to guide processes aimed at providing quality education at higher education institutions. Anchored in these values, higher education institutions are better positioned to play a pivotal role in meeting societal expectations. These expectations include production of well-rounded graduates who are equipped with requisite knowledge and skills to be able to respond to the socio-economic and development needs of their countries, to contribute positively to the advancement of technology, and to address various challenges besetting their respective nations (Pouris and Inglesi-Lotz 2014; Ekene and Oluoch-Suleh 2015). Producing graduates grounded in the 
aforementioned human values is likely to assist in promoting and protecting integrity within higher education institutions, both nationally and globally.

However, research has shown that the prospects of achieving the aforementioned goals are being hampered by academic dishonesty, a scourge prevalent in higher education institutions both nationally and globally (McCabe, Trevino and Butterfield 2001; Osipian 2008; Mohamedbhai 2016; Yang 2016; Feday 2017; O’Malley 2019). These acts of dishonesty take place at all stages in the higher education delivery value chain, from admission to assessment and certification of students (Bachore 2016). Even in research, plagiarism continues to evolve with time as dishonest students and academics persistently find ways of cheating the system (Honig and Bedi 2012; Thomas and De Bruin 2015; Singh and Remenyi 2016). These unethical practices compromise the credibility and integrity of higher education on a national and global scale.

The focus of this article is to contribute to literature by highlighting the fact that the negative consequences of acts that compromise the credibility and integrity of higher education are not confined to individuals, but rather that they reverberate throughout the national, regional and global higher education systems, and that even society at large is affected. The article argues that these practices have a snowball effect starting from the sites where they are committed and spreading to the entire higher education system.

The article examines some acts of academic dishonesty in the higher education system and the snowball effect that these acts have on different stakeholders in the higher education delivery value chain. The article is anecdotal in nature and is complemented by material from relevant secondary sources.

\section{DEFINING CREDIBILITY AND INTEGRITY}

Integrity encompasses virtues of honesty and trust, which are essential pillars for academic excellence and good governance. Credibility, according to the Cambridge English dictionary (2019), is about "being believed or trusted". In the context of this article, it refers to the confidence or faith that society has in the processes and outcomes of higher education. Similarly, academic integrity refers to the "commitment, even in the face of adversity, to values of honesty, trust, fairness, respect, responsibility and courage in learning, teaching, research and community service" (International Centre for Academic Integrity (ICAI) 1999). The key points about academic integrity are that it is the universal standard for value-based conduct for students, academics and researchers, which creates the requisite conditions for higher education to achieve its intended goals. It also provides good foundation for quality and credible higher education. Furthermore, it is holistic in nature, and does not only focus on selected activities 
and/or processes within the higher education value chain.

\section{PRACTICES THAT COMPROMISE THE CREDIBILITY AND INTEGRITY OF HIGHER EDUCATION}

Some of the practices that compromise the credibility and integrity of higher education include submission of fraudulent documents when applying for admission to institutions of higher learning and when applying for employment, plagiarism in research, cheating during examinations and tests, dereliction of teaching duties by academics, staff-facilitated corruption and the use of third party services (Eastman, Iyer and Reisenwitz 2008; Osipian 2008; Honig and Bedi 2012; Feday 2017; Shariffuddin and Holmes 2009; Bachore 2016; Kayişoğlu and Temel 2017). These acts of academic dishonesty and their snowball effects are discussed in the ensuing paragraphs. Recommendations on how to curb dishonest activities are also proffered.

\section{SUBMISSION OF FRAUDULENT DOCUMENTS}

Submission of fraudulent documents is a common practice in higher education institutions world-wide (Garwe 2015). The demand by students for university places, pressure on graduates to get employment, demand by employers to hire people with appropriate university degrees and technological skills have been cited by researchers (Garwe 2015; Simpson 2016) as some of the reasons why submission of fraudulent documentation has escalated. An example of this is a high-profile case that is before the courts in the United States of America where high-profile figures allegedly paid large amounts of money to get their children into best colleges and universities (The New York Times 2019). If found guilty, these high-profile figures are liable to prosecution.

Garwe (2015) is of the view that acts of dishonesty regarding submission of fraudulent qualifications have been further fuelled by the number of unregistered institutions that have sprouted locally and globally. Unsuspecting universities and employers often fall prey to receipt of fabricated qualifications, resulting in them registering students that have less potential to successfully complete their studies or employing graduates with limited competencies to effectively perform in their jobs (Garwe 2015). Hiring of incompetent employees is more likely to lead to lower production of goods, lower quality of produced goods, provision of poor services to clients and damage to the reputation of the organisation (Garwe 2015; Mail and Guardian 2016). Furthermore, doing so might result in loss of revenue for the organisation as clients shun its sub-standard goods and services. Curbing the use of fraudulently obtained documents and incessant abuse of academic institutional processes will go a long way in protecting the credibility and integrity of institutions of higher learning. 


\section{PLAGIARISM}

Students and researchers alike have been identified as key players in the unethical practice of plagiarism as evidenced by wide coverage of the subject in the educational research literature (Garwe 2015; O’Malley 2019; Honig and Bedi 2012; Thomas and De Bruin 2015; Shahabuddin 2009; Singh and Remenyi 2016). Researchers (Simpson 2016; Thomas and De Bruin 2015) are of the view that plagiarism has increased tremendously in higher education institutions owing to societal pressures exerted on both student and academic researchers. Families expect their members to excel in their academic work, obtain degrees and ultimately be employed (Shariffuddin 2009; Simpson 2016). Similarly, higher education institutions expect their academic staff to publish widely for subsidy and promotion purposes, which forces them to present fraudulently acquired research work for expediency (Thomas and De Bruin 2015; Chen and Macfarlane 2015; Council on Higher Education (CHE) 2017; Mouton and Valentine 2017). The Mouton and Valentine (2017) study showed how some South African higher education institutions were deeply involved in this unethical practice of publishing in predatory journals. The practice of publishing for incentives and promotion is also prevalent in China where the system is more concerned about the quantity and not the quality of papers produced (Chen and Macfarlane 2015). This exerts untold pressure on academics who are expected to steer socioeconomic development in their countries. To make matters worse, some of the plagiarised work ends up being published in predatory journals (Thomas and De Bruin 2015; Singh and Remenyi 2016; CHE 2017; Mouton and Valentine 2017) at the expense of tax payers. Tax payers' money, which could have been used to fund national development projects, such as housing, ends up funding fraudulent activities. There is, therefore, need for all stakeholders to come up with sustainable strategies to deal with plagiarism, which is undoubtedly one of the major threats to academic integrity.

\section{CHEATING IN TESTS AND EXAMINATIONS}

Cheating in tests and during examinations is a common occurrence in higher education institutions (Osipian 2008; Shariffuddin 2009; Bachore 2016). Cheating practices include the more common ones, namely passing of scribbled notes from one person to another, writing notes on the palm and copying directly from someone's answer script (Curran, Middleton and Doherty 2011). More complex ones involve the use of sophisticated gadgets, which make examination cheating difficult to detect (Kayişoğlu and Temel 2017; Shahabuddin 2009; Curran et al. 2011). This perpetuates dishonest behaviour by students, thus compromising academic integrity. Curran et al. (2011) corroborate this view and posit that technology has given cheating 
a new direction, which has escalated advanced methods of and sophisticated gadgets for cheating during examinations and tests. In addition, the availability of the Internet has exacerbated the problem of cheating in that students can readily access and read about different ways of cheating and how to execute them (Curran et al. 2011; Piascik and Brazeau 2010; Bachore 2016).

Cheating, according to researchers (Bachore 2016; Kayişoğlu and Temel 2017) is fuelled by the desire to get good grades to secure employment. Others cheat because they see their friends or classmates doing so with impunity (Bachore 2016) and some do it because they read stories of high-profile figures being implicated in these practices. Shariffuddin (2009) and Kayişoğlu and Temel (2017) are of the view that examination cheating makes student assessment difficult in that the true performance of students becomes difficult to determine. Furthermore, Kayişoğlu and Temel (2017) state that academic cheating prevents students from experiencing the true meaning of success, that is to say, students do not get to taste the fruits of hard work. It is, therefore, crucial that measures to curb examination cheating be explored and implemented.

\section{DERELICTION OF TEACHING DUTIES BY ACADEMICS}

While research and teaching are part of the core responsibilities of academics, most institutions have elevated the status of research and publication over teaching. The former also have lucrative rewards in terms of promotion and income earned through the research publication subsidy system (Thomas and De Bruin 2015; CHE 2017; Mouton and Valentine 2017). Some academics, having tasted the sweetness of research incentives, abandon their teaching duties, thereby disregarding the underlying objectives of advancing higher education. When the appetite to make money gets stronger than the need to impart knowledge, some academics might respond by teaching what they would have set in the examination question papers, precisely because they would not have enough time to work through the entire syllabus. This practice of "teaching the examinations" can lead to bright students challenging the credibility of the whole examination process, and could ultimately compromise the integrity of both the academics involved and the institution to which they are affiliated.

\section{STAFF-FACILITATED CORRUPTION}

Research has shown that academics and administrators are involved in corrupt practices of which facilitating registration of under-qualified students, accepting bribes from students in return for good grades, fabrication of students' marks by lecturers for a fee and the demand for sexual favours in return for good grades are some of them (Osipian 2008; Madara and Namango 
2016; Chinyere and Chukwuma 2017). Administrators sometimes use their positions of influence to admit and register students in higher education institutions, not based on merit, but through dubious means such as paying bribes, nepotism and patronage (Osipian 2008). Academics, on the other hand, use their influence to award marks to undeserving students, and to engage in illicit relationships with students (O’Malley 2019; Chinyere and Chukwuma 2017), as well as to leak confidential information, such as examinations, to students. All this stafffacilitated corruption has a negative impact on the integrity of students, staff members involved in this practice, and the institutions to which they are affiliated.

\section{THIRD PARTY SERVICES}

Giving assignments to students for the purposes of assessment is no longer a credible way of assessing students' performance. This is so mainly because some students use third party services such as ghost writers to do the work for them for a fee, making it difficult to gauge the real performance of those students (Shariffuddin 2009; Singh and Remenyi 2016). Some overly occupied lecturers will not even question such submissions and at the end of the day, students earn degrees for which they did not fulfil the requirements in an honest manner (Chinyere and Chukwuma 2017). People engage in such dishonest practices just to obtain qualifications and secure employment without following all the required processes and procedures (Garwe 2015). At times, third party services are used to obtain specific qualifications which will assist those involved to achieve a certain status in society, considering that society often links qualifications with high status (Garwe 2015; Simpson 2016; Feday 2017). For example, when one obtains a university degree, especially in black communities, family and other community members will celebrate showing how much they value such achievements. By so doing, students feel pressured and end up obtaining certificates yet having little or no knowledge of the subject matter. Even the writing of dissertations and theses has become easy for students as they can easily engage ghostwriters to do the work for them (Singh and Remenyi 2016). This practice threatens academic integrity.

\section{SNOWBALL EFFECTS OF ACADEMIC DISHONESTY ON VARIOUS STAKEHOLDERS LINKED TO HIGHER EDUCATION}

Whenever an act of academic dishonesty is committed there are some innocent individuals who suffer the consequences. When one person secures admission to a higher education institution through dubious means, another person who meets the requirements suffers the consequence of being denied access (Osipian 2008). Similarly, when a handful of students cheat in the examinations, the honest ones suffer the consequences of not obtaining as high a mark as those 
who cheated (Madara and Namango 2016), thereby limiting their chances of advancing to postgraduate studies. They may also be seen as less competitive and less intellectually astute on the job market because of the low pass marks.

In general, therefore, for every act of academic dishonesty, there are individuals who bear the brunt. However, this article argues and demonstrates that the negative effects of the acts of academic dishonesty do not only affect individuals, but that they have a domino effect as they move from individuals to the entire cohort of students, then the higher institution concerned, the broad higher education sector, the economic system, the socio-cultural system and so on. This is the snowball effect of these practices (Eastman et al. 2008; Garwe 2015; Madara and Namango 2016; Mohamedbhai 2016; Singh and Semenyi 2016; Chinyere and Chukwuma 2017. Figure 1 illustrates this snowball effect.

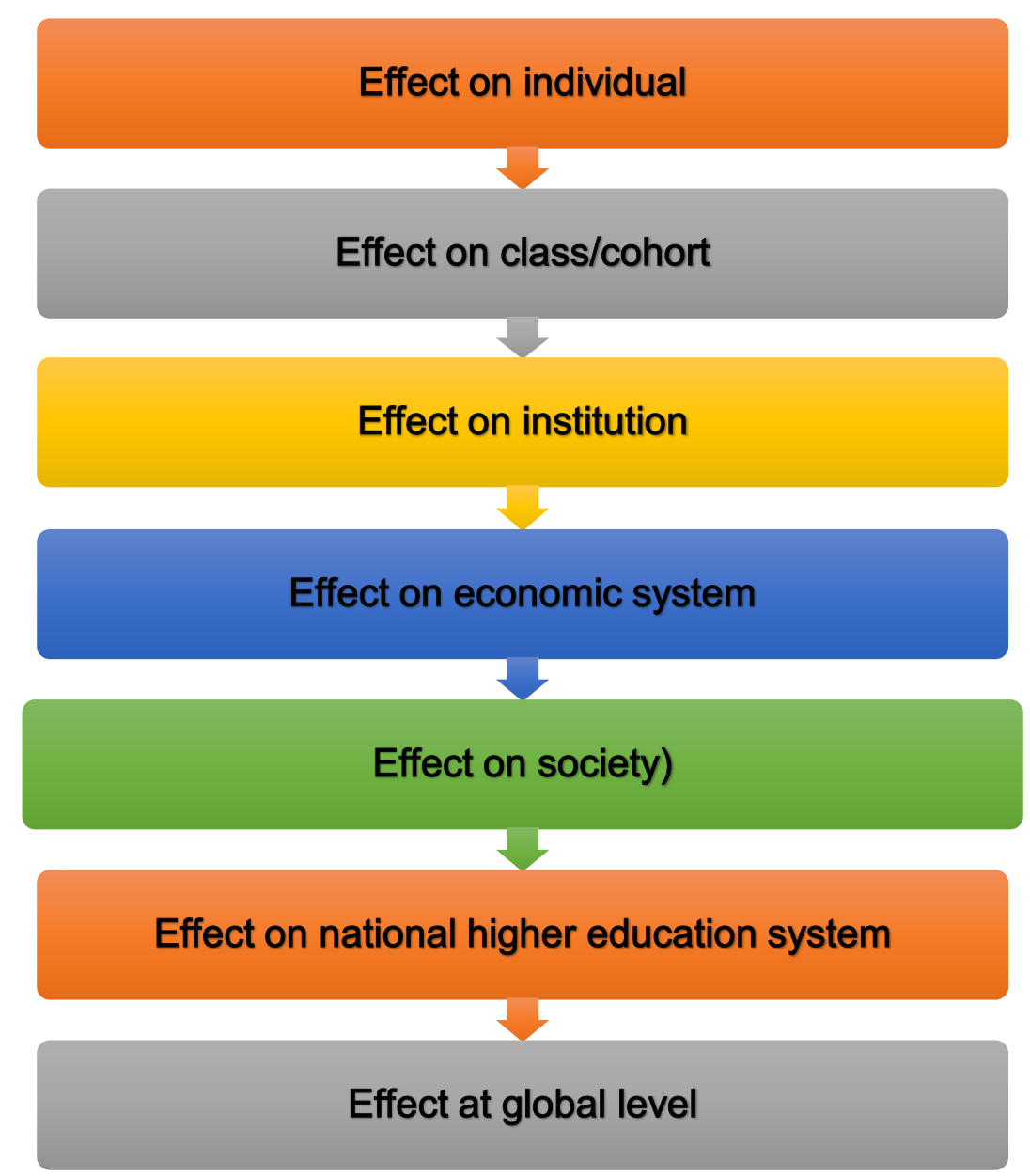

Figure 1: Illustration of the snowball effects of practices that compromise the credibility and integrity of Higher Education

\section{AT INDIVIDUAL LEVEL}

Individuals shoulder financial costs for paying bribes and for services rendered by third party 
agents such as ghostwriters and degree mills (Garwe 2015). This they do for various reasons, including pressure to perform well, the need for employment, failure to budget their time, difficult tasks given to them by their lecturers and lack of resources from where they can access information (Shariffuddin 2009; Bachore 2016; Simpson 2016). Through these corrupt practices, students cheat the system and ultimately achieve good grades and certificates for the work they did not do. This gives them an unfair advantage over students who would have worked hard to achieve good grades. Such dishonest practices tend to have a negative effect on the morale of those hardworking students who might start to question the value of working hard. These dishonest practices taint the good image of well deserving students (Madara and Namango 2016).

Besides, well deserving students may be denied access to higher education institutions because other students would have been offered those places, without regard to merit, but through fraudulent practices such as using fake documents, nepotism or admitting relatives (Deliversky 2016; Chinyere and Chukwuma 2017).

Such practices are also used to tilt the scales in favour of the well-connected students and students from affluent families to secure places at higher education institutions (Chinyere and Chukwuma 2017). Unethical acts such as these result in "inequity among, and unfairness to individuals" (Osipian 2008; Madara and Namango 2016; Chinyere and Chukwuma 2017), thereby costing them their right to education.

Individual students can also be financially exploited by paying service providers who are not qualified to perform the tasks in which they purport to be experts. An example of this is when students, out of frustration of not accessing higher education institutions, ultimately enrol in institutions that are not properly registered and/or accredited by the relevant authorities, and which employ unqualified teaching staff. These unregistered institutions are found everywhere (Garwe 2015; University World News 2015). The Timeslive (2018) and the Citizen (2019) carried articles in which the Department of Higher Education and Training (DHET) was warning students and their parents to be aware of these bogus institutions. The DHET went as far as giving students the link to check whether or not the institutions they wished to apply to were registered with them. Qualifications obtained from such institutions are considered of no value because they are not recognised by the relevant authorities, and yet obtained at a cost (Timeslive 2018).

Deserving graduates might also fail to secure employment because jobs would have been given to those with fraudulent qualifications. Faced with such corrupt processes, well-deserving graduates might be tempted to also engage in corrupt practices to increase their chances of employability yet compromising their moral values in the process (Bachore 2016). Feday 
(2017) and Madara and Namango (2016) corroborate this view and postulate that academic dishonesty affects individuals themselves in that their reputation will be tarnished and they might face life time humiliation which might lead to low self-esteem. This creates a vicious cycle.

\section{AT CLASS/COHORT LEVEL}

The good image of the whole class can get tainted because of the actions of a few dishonest individuals. When a student cheats in an examination, the whole class would be referred to as a "class of cheats" despite the fact that only a few students were involved in the dishonest act. An example of this is the matric class of 2014 which was associated with examination cheating on a grand scale. Timeslive (2015) and RNews (2014) were abuzz with stories of matric cheating that had been uncovered in seven out of the nine South African provinces, with Kwa-Zulu Natal, the Eastern Cape and Gauteng topping the list of offenders. The stigma attached to that class will take some time to be erased. Also, quite recently, the Eyewitness News (2019) carried a story about the "May/June examination leakage scandal" that presumably took place at the University of South Africa (UNISA) involving students in the human sciences, economic management sciences and accounting sciences. It was reported that if the claim was found to be true, the students in the affected disciplines would have to rewrite the examination and the students involved in the scandal would face prosecution. If that were to happen, all the students including the innocent ones would be affected.

Also, examinations can get cancelled or their results nullified after discovering evidence of paper leaks or extensive cheating (Madara and Namango 2016). Such cancellation of examinations or nullification of results would affect entire classes or cohorts of students who have to make preparations again to sit for the examinations. Furthermore, the stigma of belonging to a "class of cheats" lasts for long periods of time, and such stigma brings along prejudice and other negative consequences. Academic dishonesty which includes examination cheating, endangers quality in that the value and integrity of marks and awards becomes compromised (Bachore 2016; Madara and Namango 2016; Kayişoğlu and Temel 2017).

\section{AT INSTITUTIONAL LEVEL}

Higher education institutions are equally affected by practices of academic dishonesty. Clearly, academic corruption tarnishes the image and reputation of an institution (Deliversky 2016; Madara and Namango 2016; Feday 2017). Singh and Remenyi (2016) share similar sentiments and posit that academic cheating has a negative impact on the institution and also puts a dent on the integrity of the faculty and students. Rozzet, Hage and Chow (2011) and Madara and 
Namango (2016) are of the view that academic dishonesty impacts negatively on educational institutions in that it not only becomes hard for them to attain their educational goals, but it also becomes difficult for academics to properly assess and address the knowledge gaps in students' work. This will, in turn, have an impact on the reputation of the institution. Feday (2017) adds weight to the argument and states that academic dishonesty affects the quality of education and because of that, academic dishonesty, higher education institutions stand the risk of producing "semi educated" professionals. These "half-baked" individuals would undoubtedly be found wanting when they are eventually absorbed into the job market. It is therefore incumbent upon higher education institutions to protect their good image at all costs.

\section{AT ECONOMIC SYSTEM LEVEL}

The demand for employment by job seekers and the need to recruit people with credible qualifications has created challenges for employers (Garwe 2015). Employers fall prey to job seekers producing fraudulent qualifications to increase their prospects of securing the muchneeded jobs (Garwe 2015). Employees hired based on fake qualifications are likely to be found incompetent as their qualifications would not have been obtained on merit or the processes leading to graduation and certification might have been tainted. In 2014, the South African Broadcasting Corporation (SABC) News carried stories of high-profile cases of personalities who were employed as chairpersons of various boards who had misrepresented or falsified their qualifications. Employing people with compromised competencies often affects production in an organisation, either in the form of low-quality goods or poor services (Garwe 2015; Mail and Guardian 2016). Acts of dishonesty might even expose other employees to risks (Garwe 2015; Madara and Namango 2016; Feday 2017; O’Malley 2019) because of sub-standard products and services offered. The production of sub-standard goods and the provision of substandard services might also result in the organisation's reputation being tainted (Mail and Guardian 2016; Feday 2017), leading to deteriorating standards in as far as the production of goods and provision of services is concerned.

Graves (2008) is of the view that students who engage in dishonest activities during their academic years at higher education institutions are likely to exhibit that behaviour in the work place. Dishonest behaviour impacts negatively on the national economy in that tax payers' money invested in funding higher education would not be properly utilised. Deliversky (2016) shares similar sentiments and postulates that educational corruption impacts negatively on financial resources of institutions. The return on investment of tax money would be negative, and yet such funds would have been utilised for other social development programmes such as health, social grants and housing, among many other government imperatives. Where higher 
education lacks credibility and integrity, it will fail to live up to the societal expectation of being the lever for social and economic development (Deliversky 2016).

\section{AT SOCIETAL LEVEL}

The perpetuation of unethical behaviour by students and academics can impact society negatively in that society will not know who to trust (Madara and Namango 2016). Lack of trust among communities might have a negative impact on social cohesion. Where there is no social cohesion, communities are likely to lag behind in development. Furthermore, if higher education institutions fail to produce quality research innovations and society does not take advantage of technological development, then its development might be curtailed (Serdyukov 2017).

Brimble and Stevenson-Clarke (2005) and Madara and Namango (2016) believe that if students do not value academic integrity during their university education, there is a likelihood that they will exhibit the same traits in their social life and in their relationships. If human virtues of honesty, respect, responsibility, trust and integrity are not inculcated in students by higher education institutions, then anti-social behaviour is likely to manifest. When anti-social behaviour is on the increase, then anarchy becomes the norm and where there is anarchy, growth and development might be curtailed which might lead to other problems such as poverty and joblessness.

\section{AT NATIONAL HIGHER EDUCATION SYSTEM LEVEL}

The effects of dishonesty at higher educational levels can also be catastrophic nationally. National higher education systems whose credibility and integrity are compromised might find it hard to attract international students and academic staff of good repute (Denisova-Schmidt 2017). The result is that they might lose the many benefits attached to internationalisation of higher education which include exchange of knowledge, international exposure for both students and academics, generation of revenue and knowledge of other cultures (Jibeen and Khan 2015). Furthermore, academic dishonesty can negatively impact national higher education systems in that they stand to lose their own gifted students and academics as they seek educational opportunities in systems that are perceived to be more credible. This brain drain might, in the long run, have an adverse effect on national educational systems.

\section{AT GLOBAL LEVEL}

Globally, countries with higher education systems that retain higher levels of credibility and integrity lead the pack in terms of social and economic development, whereas those whose 
higher education systems lack credibility and integrity lag on most indicators of social and economic development (Organisation for Economic Co-operation and Development (OECD) 2017). Another downside of academic dishonesty is that, because we live in a global village, what happens in one country has a potential of positively or negatively affecting other countries (Denisova-Schmidt 2017). If the behaviour of the citizens of one country is undesirable, academic malpractice will be perpetuated if such citizens migrate. Moreover, technology has made it easier for corruption to permeate through borders, making all countries vulnerable to acts of dishonesty and criminality (United Nations Office on Drugs and Crime (UNDC) 2017). The points raised in this article make curbing acts of academic dishonesty more compelling.

\section{RECOMMENDATIONS ON HOW TO ADDRESS ACADEMIC DISHONESTY}

As research has shown, academic dishonesty is a scourge that is deeply engrained in higher education institutions. Fighting it will require collective effort from all role players involved within the higher education sector.

The starting point to address the negative effects of academic dishonesty will be for higher education institutions to acknowledge that such a problem exists in their respective institutions. Acknowledging the existence of a problem gives all stakeholders, namely students, academic and non-academic staff and university management, an opportunity to engage each other on the issue with a view to developing practical solutions to curb the menace.

Management in higher education institutions can also play an important role in sensitising the university community about issues of credibility and integrity with a view to garnering support from lecturers and students to combat the scourge. This can be done through awarenessraising programmes, open discussion foras and induction courses for students. The awareness programmes can focus on issues such as identification of the reasons students and academics engage in dishonest practices, practices that compromise academic credibility and integrity, the effects of those practices on various stakeholders and what could be done to fight this social ill.

Creating platforms such as colloquia, seminars and conferences where such issues are openly discussed will go a long way in drawing the attention of the participants to the problem and its magnitude and the need to come up with sustainable solutions to the problem. Exchanging information with other universities on academic dishonesty and the current trends used by the perpetrators would likely assist universities to keep abreast of the latest information on academic dishonesty and to be vigilant in fighting such practices and the perpetrators of such acts.

Creating a healthy learning environment for both students and academics would require combined efforts from all role players in higher education. An all-inclusive stakeholder 
approach, where stakeholders work as a collective towards the same goal of curbing academic dishonesty is likely to yield positive results in assisting higher education institutions achieve their goals.

\section{CONCLUSION}

The article brought to the fore the snowball effects of the impacts of practices that compromise the credibility and integrity of higher education. When individuals breach principles of academic integrity, the effects are far-reaching and go beyond just the individuals concerned. The magnitude of the snowball effects is amplified at each stage, from individuals, class or cohort, institutions, economic system, society, national higher education system and across the globe. It is, therefore, important to curb all practices that are likely to compromise credibility and integrity because dealing with consequences will be too costly. Achieving this would require collaborative efforts and commitment from all stakeholders in higher education, namely students, academics, non-academics and society as a whole.

\section{REFERENCES}

Bachore, M. M. 2016. The nature, causes and practices of academic dishonesty/cheating in higher education: The case of Hawassa University. Journal of Education and Practice 7(19). ISSN 22221735.

Brimble, M. and P. Stevenson-Clarke. 2005. Perceptions of the prevalence and seriousness of academic dishonesty in Australian universities. The Australian Educational Researcher 32(3): 19-44.

Cambridge English Dictionary. 2019. Cambridge University Press. https://dictionary.cambridge.org/ dictionary/english/credibility (Accessed 29 March 2019).

Chen, S. and B. Macfarlane. 2015. Academic integrity in China. Handbook of academic integrity. Springer Science+ Business Media Singapore. http://doi.org/10.1007/978-981-287-079-7_32-1

Chinyere, A. P. and O. Chukwuma. 2017. Corruption and administration of higher education institutions in Nigeria. World Journal of Social Science 4(2). http://doi.org/10.5430/wjss.v4n2p12

Citizen. 2019. Education department warns about bogus colleges. https://citizen.co.za./news/southafrica/general/2058655/education-department-warns-about-bogus-colleges/ (Accessed 30 October 2019).

Council on Higher Education. 2017. BrieflySpeaking. Research Ethics: 1.

Curran, K., G. Middleton and C. Doherty. 2011. Cheating in exams with technology. International Journal of Cyber Ethics in Education 1(2): 54-62. DOI: 10.4018/ijcee.2011040105

Denisova-Schmidt, E. 2017. The challenges of academic integrity in higher education: Current trends and prospects. CIHE Perspectives 5. The Boston College Center. International Higher Education.

Deliversky, J. 2016. Preventing corruption in the education system. Journal of Educational and Instructional Studies in the World 6(1) Art 20.

Eastman, J. K., R. Iyer and T. H. Reisenwitz. 2008. The impact of unethical reasoning on different types of academic dishonesty: An exploratory study. Journal of College Teaching \& Learning 5(12). https://doi.org/10.19030/tlc.v5i12.1211

Ekene, O. G. and E. Oluoch-Suleh. 2015. Role of institutions of higher learning in enhancing sustainable development in Kenya. Journal of Education and Practice 6(16). ISSSN 2222-288X. 
Eyewitness News. 2019. Unisa students "to rewrite exams" if probe backs claims of question paper leaks. https://ewn.co.za/2019/05/24/unisa-students-to-rewrite-exams-if-probe-back-claims-of-questionpaper-leaks (Accessed 30 October 2019).

Feday, S. W. 2017. Academic dishonesty in Ethiopian higher education and its implication for corruption. Beijing Law Review 8: 10-20. https://doi.org/10.4236/blr.2017.81002

Garwe, E. C. 2015. Qualification, award and recognition fraud in higher education in Zimbabwe. Journal of Studies in Education 5(2). http://dx.doi.org/10.5296/jse.v5i2.7456

Graves, S. M. 2008. Student cheating habits: A predictor of workplace deviance. Journal of Diversity Management 5(1): 15-21.

Honig, B. and A. Bedi. 2012. The fox in the hen house: A critical examination of plagiarism among members of the academy of management. Academy of Management Learning and Education 11(1): 101-123. http://dx.doi.org/10.5465/amle.2010.0084

Jibeen, T. and M. A. Khan. 2015. Internalisation of higher education: Potential benefits and costs. International Journal of Evaluation and Research in Education 4(4): 196-199

Kayişoğlu, N., B. C. Temel. 2017. An examination of attitudes towards cheating in exams by physical education and sports high school students. Universal Journal of Educational Research 5(8): 13961402. http://www.doi.org/10.13189/ujer.2017.050813

Madara, D. S. and S. S. Namango. 2016. Faculty perception on cheating in exams in undergraduate engineering. Journal of Education and Practice 7(30): 70-86.

Mail and Guardian. 2016. How the Motsoenang saga has damaged SABC's reputation and insulted the judiciary. https://mg.co.za/article/2016-09-26-how-the-sabc-thumbs-its-nose-at-the-law-withthe-motsoeneng-saga (Accessed 12 June 2012.)

McCabe, D. L., L. K. Trevino and K. D. Butterfield. 2001. Cheating in academic institutions: A decade of research. Ethics \& Behaviour 11(3): 219-232. https://doi.org/10.1207/S15

Mohamedbhai, G. 2016. The scourge of fraud and corruption in higher education. International Higher Education 84: 12-14. https://doi.org/10.6017/ihe.2016.84.9111

Mouton, J. and A. Valentine. 2017. The extent of South African authored articles in predatory journals. South African Journal of Sciences 113(7/8), Art. \#2017-0010, 9 pages. http://dx.doi.org/1017159/ sajs.2017/20170010

New York Times. 2019. Actresses, business leaders and other wealthy parents charged in U.S. college scandal. https://www.nytimes.com/2019/03/12/us/college-admissions-cheating-scandal.html (Accessed 10 June 2019).

OECD see Organisation for Economic Co-operation and Development.

O'Malley, B. 2019. Call to fight the spread of corruption in higher education globally. University World News 13 April.

Organisation for Economic Co-operation and Development. 2017. Education at a glance: OECD indicators. https://www.oecd-ilibrary.org/docserver/eag-2017-en.pdf?expires=1555407272\&id= id\&accname $=$ guest $\&$ checksum=36A2A438B666D4C8B0474E91FA08A22C (Accessed 16 April 2019).

Osipian, A. L. 2008. Corruption in higher education: Does it differ across the nations and why? Research in Comparative and International Education 3(4): 345-365. http://dx.doi.org/10.2304/rcie. 2008.3.4.345

Piascik, P. and G. A. Brazeau. 2010. Promoting a culture of academic integrity. American Journal Pharmaceutical Education 74(6): Art 113. https://doi.org/10.5688/aj7406113

Pouris, A. and R. Inglesi-Lotz. 2014. The contribution of higher education institutions to the South African economy. South African Journal of Science 110(3/4), Art \#a0059, 5 pages. http://dx.doi. org/10.1590/sajs.2014/a0059

RNews. 2015. Class 2014: Matric exam cheating being investigated at Western Cape independent school.

https://www.rnews.co.za/article/2306/class-of-2014-matric-exam-cheating-being- 
investigated-at-western-cape-independent-school

Rozzet, J., H. S. Hage and H. P. H. Chow. 2011. Academic dishonesty in the Canadian classroom: Behaviours of a sample of university students. Canadian Journal of Higher Education 41(3): 135 .

Serdyukov, P. 2017. Innovation in education: What works, what doesn't, and what to do about it? Journal of Research in Innovative Teaching and Learning 10(1): 4-33. DOI 10.1108 JRIT-102016-0007.

Shahabuddin, S. 2009. Plagiarism in academia. International Journal of Teaching and Learning in Higher Education 2(3): 353-359 http://www.isetl.org/ijtlhe/

Shariffuddin, S. A. and R. J. Holmes. 2009. Cheating in examinations: A study of academic dishonesty in a Malaysian College. Asian Journal of University Education 5(2): 99-124.

Simpson, D. 2016. Academic dishonesty: An international student perspective. Higher Education \& Economics 2(1) Art 5.

Singh, S. and D. Remenyi. 2016. Plagiarism and ghostwriting: The rise in academic misconduct. South African Journal of Sciences 112(5/6), Art \#2015-03000, 7 pages. http://dx.doi.org/10.17159/ sajs.2016/20150300

Timeslive, 2015. Matric cheats uncovered in seven out of nine provinces. https://www.timeslive.co.za/ news/south-africa/2015-01-04-matric-cheats-uncovered-in-seven-out-of-nine-provinces/ (Accessed 23 April 2019).

Timeslive. 2018. Fake colleges on the rise and destroying SA education. https://www.timeslive.co.za/ sebenza-live/features/2018-01-09-fake-colleges-on-the-rise-amp-destroying-sa-education/ (Accessed 12 June 2019).

The International Center for Academic Integrity. 1999. The fundamental values of academic integrity. The International Center for Academic Integrity, Duke University.

Thomas, A. and G. P. de Bruin. 2015. Plagiarism in South African management journals. South African Journal of Sciences 111(1/2), Art \#2014-0017, 3 pages. http://dx.doi.org/10.17159/sajs. 2015/20140017

United Nations Office on Drugs and Crime. 2017. In just two decades, technology has become a cornerstone of criminality. https://www.unodc.org/unodc/en/frontpage/2017/October/in-just-twodecades-technology-has-become-a-cornerstone-of-criminality.html (Accessed 16 April 2019).

UNODC see United Nations Office on Drugs and Crime.

University World News. 2015. Bogus colleges and qualifications: Is supervision lax? https://www. universityworldnews.com/post.php?story=20150611144912624 (Accessed 12 June 2019).

Yang, R. 2016. Toxic academic culture in East Asia. International Higher Education Winter 84: 15-16. https://doi.org/10.6017/ihe.2016.84.9112 